\title{
Experience of a Portuguese Center: Effectiveness of Direct- Acting Antiviral Therapy for Hepatitis C
}

\author{
Experiência de um Centro Português: Eficácia dos \\ Antivirais de Acção Directa no Tratamento da Hepatite C
}

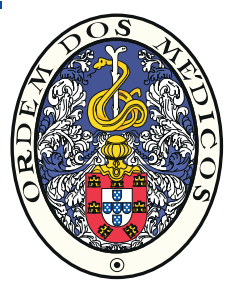

\begin{abstract}
Fátima FALCÃO $\rrbracket^{1,2,3}$, Carla LOPES ${ }^{2}$, Erica VIEGAS ${ }^{1,2,3}$, Rita PEREZ ${ }^{1}$, Isabel ALDIR ${ }^{1,4}$, Helena FARINHA FA, $^{1,2}$ António CARVALHO ${ }^{1}$, Ana MIRCO ${ }^{1,2,3}$, Susana MARQUES ${ }^{5}$, Tiago BANA E COSTA ${ }^{5}$, Ana Cláudia MIRANDA ${ }^{4}$, Luís LEBRE ${ }^{5}$, Paula PEIXE ${ }^{5}$, Cristina $\mathrm{CHAGAS}^{5}$, Kamal MANSINHO ${ }^{4}$, José Manuel CORREIA ${ }^{1}$
\end{abstract}

Acta Med Port 2019 Mar;32(3):189-194 - https://doi.org/10.20344/amp.10655

\section{ABSTRACT}

Introduction: In late 2014, Portugal implemented a national program for the treatment of patients with chronic hepatitis $\mathrm{C}$ with directacting antiviral agents. This program has made Portugal one of the first European countries to implement a structured measure of treatment to eliminate this serious public health problem. The aim of this study was to assess the effectiveness of direct-acting antiviral therapy in the treatment of patients with chronic hepatitis $C$ virus infection.

Material and Methods: A retrospective observational study was conducted at Centro Hospitalar de Lisboa Ocidental on the national online platform from December 2014 until February 2017 and included patients with hepatitis C virus infection who underwent treatment. The primary endpoint was sustained virologic response at least 12 weeks post treatment. Data was analyzed with the SPSS 17.0 program.

Results: During the study period, 820 patients completed therapy and achieved sufficient follow-up time to assess sustained virologic response with an overall response rate of $97.2 \%(n=797)$ and a response rate of $98.0 \%, 99.5 \%, 90.9 \%, 95.1 \%$ and $94.2 \%$ for genotypes 1a, 1b, 2, 3 and 4, respectively. Data suggested that advanced fibrosis (F3/F4), human immunodeficiency virus co-infection and treatment failure with interferon and ribavirin were not negatively related with sustained virologic response in our population. Most patients $(80.1 \%)$ completed treatment with ledipasvir/sofosbuvir \pm ribavirin. The most common adverse events were fatigue and insomnia followed by headache and weight loss.

Discussion: Patients predominantly had genotype 1 infection which correlates with HCV distribution in Europe, but we found a major proportion in genotype 4 which can be explained by immigration from African countries. Our patients' ages ranging from 22 to 90 years, reflected a new approach with no upper age limit. Direct-acting antivirals regimens resulted in remarkably high SVR rates compared to interferon-based regimens, which were consistent with clinical trials data.

Conclusion: Our data showed that direct-acting antiviral-based regimens are safe and have a high success rate in the treatment of patients with hepatitis $C$ virus infection in a real-world setting.

Keywords: Antiviral Agents/therapeutic use; Hepacivirus/drug effects; Hepatitis C/drug therapy; Portugal

\section{RESUMO}

Introdução: No final de 2014 foi implementado em Portugal um programa nacional para o tratamento de doentes com infecção crónica por vírus da hepatite $\mathrm{C}$ com recurso a antivíricos de acção directa. Este programa fez com que Portugal fosse um dos primeiros países europeus a implementar uma medida estruturante para a eliminação da hepatite C. Este estudo tem como objectivo a avaliação da efectividade dos antivíricos de acção directa no tratamento da hepatite $\mathrm{C}$ crónica.

Material e Métodos: Estudo retrospectivo observacional dos doentes seguidos no Centro Hospitalar de Lisboa Ocidental, entre dezembro de 2014 e fevereiro de 2017. O objectivo primário do estudo é avaliar a resposta virológica sustentada a partir das 12 semanas pós tratamento. Analisámos os dados com o programa SPSS 17.0.

Resultados: Durante o período do estudo 820 doentes completaram o tratamento e o tempo necessário para avaliação da resposta virológica sustentada. A resposta virológica sustentada global foi de $97.2 \%$ ( $n=797$ ), com taxas de resposta de 97,2\%, 98,5\%, 90,9\%, $95,1 \%$ e $94,2 \%$ para os genótipos 1a, 1b, 2, 3 e 4, respectivamente. Os dados sugerem não haver relação entre a fibrose avançada (F3 ( F4), a coinfecção pelo vírus da imunodeficiência humana e a falência do tratamento com interferão e ribavirina e uma menor resposta ao tratamento. A maioria dos doentes $(80,1 \%)$ concluiu o tratamento com ledipasvir/sofosbuvir \pm ribavirina. Os eventos adversos mais frequentes foram a fadiga e a insónia, seguida de dor de cabeça e perda de peso.

Discussão: A população em estudo apresentou maior prevalência de infecção pelo genótipo 1, à semelhança dos restantes países Europeus, contudo a prevalência do genótipo 4 foi superior, reflectindo a imigração africana. A faixa etária (22 - 90 anos) dos doentes tratados reflecte uma nova abordagem sem limite superior de idade. A taxa de RVS obtida, muito superior à obtida com regimes baseados em interferão, foi consistente com os dados dos ensaios clínicos.

Conclusão: Os dados encontrados demonstram que os regimes baseados em antivirais de acção directa, em contexto de vida real, são seguros e eficazes no tratamento de doentes com infecção por vírus da hepatite $C$.

Palavras-chave: Antivirais/uso terapêuttico; Hepatite C Crónica/tratamento; Portugal; Vírus da Hepatite C/efeitos dos fármacos

\footnotetext{
1. Pharmacy and Therapeutics Committee. Centro Hospitalar de Lisboa Ocidental. Lisboa. Portugal.

2. Pharmacy Department. Centro Hospitalar de Lisboa Ocidental. Lisboa. Portugal.

3. Department of Pharmacy Practice. Faculty of Pharmacy. University of Lisbon. Lisboa. Portugal.

4. Infecciology. Hospital de Egas Moniz. Centro Hospitalar de Lisboa Ocidental. Lisboa. Portugal.

5. Gastroenterology. Hospital de Egas Moniz. Centro Hospitalar de Lisboa Ocidental. Lisboa. Portugal.

$\triangle$ Autor correspondente: Fátima Falcão. mffalcao@chlo.min-saude.pt

Recebido: 09 de maio de 2018 - Aceite: 11 de setembro de 2018 | Copyright @ Ordem dos Médicos 2019
} 


\section{INTRODUCTION}

The rapid development of new treatments for hepatitis $\mathrm{C}$ virus $(\mathrm{HCV})$ over the last years with the introduction of all oral direct-acting antivirals made highly effective, welltolerated and interferon-free (IFN-free) regimens available. The introduction of direct-acting antivirals started with boceprevir or telaprevir plus peginterferon alfa and ribavirin. Due to the side effect profiles and costs, they are no longer used. Other more efficacious and better tolerated options such as sofosbuvir and ledipasvir/ sofosbuvir, simeprevir, daclatasvir, ombitasvir/ paritaprevir/ ritonavir and dasabuvir are now available. As a result, the majority of patients chronically infected with the hepatitis $C$ virus can be successfully treated with oral medications. These therapeutic regimens were reported in clinical trials to have sustained virologic response (SVR) rates exceeding 90\% with the best response in genotype 1 as compared with genotypes 2 and $3 .^{1-4}$

Since December 2014, Portugal started a new strategy for the treatment of Hepatitis $\mathrm{C}$ based on a financing model and a universal access policy in order to guarantee the treatment of all patients registered with the National Health Service. The aim of this program, besides the elimination of hepatitis $C$ virus infection among diagnosed patients on follow-up, was to improve the life expectancy and quality of life of patients with chronic hepatitis $\mathrm{C}$. The first oral direct-acting antivirals available in the program were sofosbuvir and ledipasvir/ sofosbuvir. During the study period simeprevir, daclatasvir, ombitasvir/ paritaprevir/ ritonavir and dasabuvir were allowed with restrictions. The program uses electronic medical records exclusively through the Portal da Hepatite $C$, a national, continually updated repository of data managed by the Portuguese National Authority of Medicines and Health Products (INFARMED). The submitting hospital center, Centro Hospitalar de Lisboa Ocidental (CHLO), only has access to its own patient data through the Portal da Hepatite $C$. This data includes patients' characteristics and drug dispensing data as well as drug results in terms of efficacy and safety.

We conducted a study to assess the results of $\mathrm{HCV}$ treatment with direct-acting antivirals in all patients who underwent treatment at CHLO regardless of HCV genotype, HIV co-infection or prior treatment experience.

\section{MATERIAL AND METHODS}

\section{i. Study design and patients}

The CHLO Pharmacy and Therapeutics Committee (P\&T) performed a retrospective observational study on patients with chronic hepatitis $\mathrm{C}$ who were treated with oral direct-acting antivirals at CHLO. Only patients who completed treatment and had sufficient follow-up time to assess SVR12 between December 2014 and February 2017 in this Hospital Center were included. SVR12 is defined as HCV RNA 12 weeks below the limit of quantification $(<15 \mathrm{IU} / \mathrm{mL}$ or undetectable) after treatment completion.

Accordance to national and/ or European Association for the Study of the Liver (EASL) guidelines was evalu- ated by CHLO P\&T. All patients were counseled by hospital pharmacists prior to receiving their medication. Data related to adverse drug reactions were collected through standard-of-care operating procedures according to the national network for pharmacovigilance. Liver elastography or METAVIR score were used to assess the extent of inflammation and fibrosis (F0/ F1/ F2 for no, mild or moderate disease and F3/F4 for significant fibrosis or cirrhosis). The primary endpoint was the proportion of patients who achieved SVR12 also known as responders while the rest of the patients were considered relapsers.

\section{ii. Technical information}

Portal da Hepatite $C$ is a national platform that tracks the management of chronic hepatitis $\mathrm{C}$ treatment (prescription, approval, dispensing and monitoring). It includes patient characteristics, namely birth date, gender, prior antiviral regimen (treatment experienced patients), fibrosis stage, laboratory tests at baseline, direct-acting antivirals regimen requested and approved, drug dispensing dates and viral load data.

\section{iii. Statistics}

Descriptive statistics were obtained for the study population. Continuous variables were expressed as medians (interquartile range) and categorical variables as percentage. The software Statistical Package for the Social Sciences (SPSS version 17) was used for statistical analysis.

\section{RESULTS}

During the study period, there were 1103 requests for treatment recorded in the platform. Two hundred eightythree were excluded: 136 didn't start treatment, 45 were lost to follow-up or data of SVR12 was unavailable, 38 discontinued therapy, 38 remained on treatment and 26 had insufficient follow-up time to assess SVR12 (Fig. 1). Out of the 1103 requests for treatment 820 patients met the inclusion criteria and were enrolled in the study.

Of the 820 patients enrolled, $67.4 \%$ were male with $1.8 \%(n=14) \geq 80$ years of age. Patients' ages ranged from a minimum of 22 to a maximum of 90 years (median age 50 years; IQR, 45 to 57 ). The majority of patients were infected with genotype $1(66.7 \%)$ with $64.6 \%$ with a HCV viral load $>800000 \mathrm{IU} / \mathrm{mL}$. A total of $53.2 \%$ of patients had significant fibrosis or cirrhosis, and $30.1 \%$ were treatmentexperienced. HIV coinfection was present in 262 patients $(32 \%)$.

The majority of patients received treatment with ledipasvir/sofosbuvir or sofosbuvir, according to the regulatory situation and recommendations at the time the data was recorded on the Portal da Hepatite C (Fig. 2).

The most common adverse events were fatigue (1.6\%), insomnia $(1.3 \%)$ and headache $(1.1 \%)$, followed by anemia $(0.7 \%)$. Two patients experienced serious adverse events (pancreatitis and venous thrombosis). A new or recurrent hepatocellular carcinoma was detected during follow-up in 


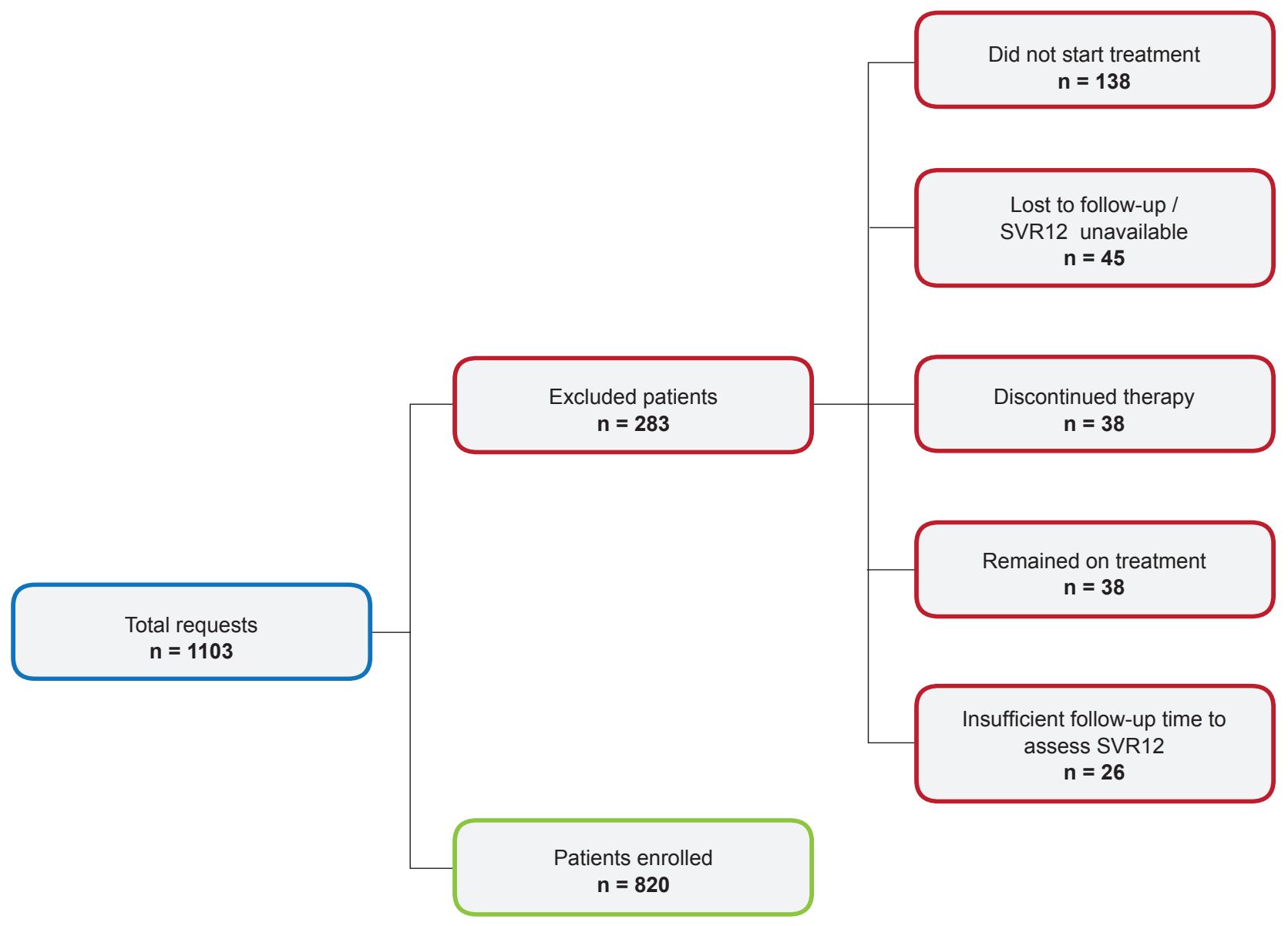

Figure 1 - Study population

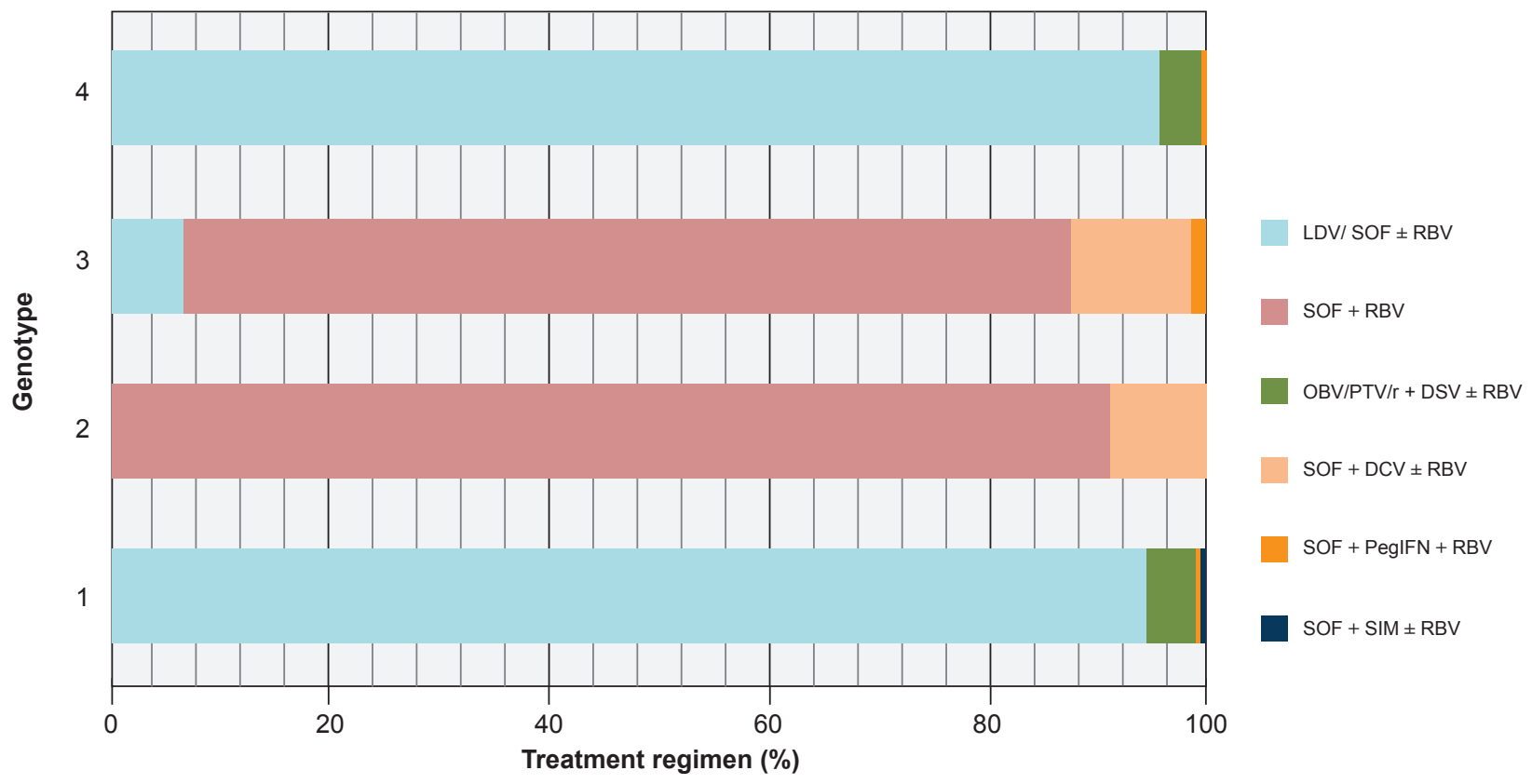

Figure 2 - Treatment regimens for genotypes 1, 2, 3 and 4

LDV/ SOF \pm RBV: ledipasvir/ sofosbuvir \pm ribavirin; SOF + RBV: sofosbuvir + ribavirin; OBV/PTV/r \pm DSV \pm RBV: ombitasvir/ paritaprevir/ ritonavir \pm dasabuvir \pm ribavirin; SOF + DCV \pm RBV: sofosbuvir + daclatasvir \pm ribavirin; SOF + PegIFN + RBV: sofosbuvir + pegylated interferon + ribavirin; SOF + SIM \pm RBV: sofosbuvir + simeprevir \pm ribavirin 
three patients.

The overall SVR12 rate was $97.2 \%(797 / 820)$ as shown in Table 1. The highest success rate was seen in patient with genotype $1 \mathrm{~b}$ infection. The majority of genotype 3 infected patients $(93.4 \% ; n=114)$ were treated for 24 weeks. The SVR12 rate was $97.4 \%$ in those treated with ledipasvir/ sofosbuvir \pm ribavirin (642/659), $96.4 \%$ in those treated with sofosbuvir plus ribavirin (106/110), 100\% (28/28) in those treated with ombitasvir/paritaprevir/ritonavir \pm dasabuvir \pm ribavirin and $92.9 \%(13 / 14)$ in those treated with sofosbuvir plus daclatasvir \pm ribavirin.

A total of 23 patients did not achieve an undetectable HCV RNA level at SVR12. Patients were categorized as responders $(n=797)$ and relapsers $(n=23)$. The demographic and baseline clinical characteristics are shown in Table 2.

Previously treated patients with HCV genotypes 3 and 4 infection, HCV RNA viral load $>800000 \mathrm{lU} / \mathrm{mL}$, and advanced hepatic fibrosis or cirrhosis had the lowest rate of SVR12.

\section{DISCUSSION}

This retrospective study assesses the results of HCV treatment with direct-acting antivirals at a Portuguese Hospital Center. Previous data obtained from two national surveys on HCV epidemiology in Portugal: one in 2001 had 618 participants ( $75 \%$ male, mean age 38 years) and one in 2009 had 1907 participants (68\% male, mean age 41 years). ${ }^{5,6}$ We found a similar proportion of male subjects in our population, but the hospital data showed patients' ages ranging from a minimum of 22 to a maximum of 90 years, reflecting a new treatment approach in which there is no upper age limit.

Patients in our population predominantly had genotype 1 infection (66.7\%), which correlates with HCV genotype distribution in Europe. Genotype 1 infection accounts for $64.4 \%$ of all infections, followed by genotype 3 at $25.5 \%$. Genotypes 2 and 4 only account for $5.5 \%$ and $3.7 \%$, respectively. ${ }^{7}$ As seen in the southern European countries, we found a discrepancy observed in genotype 4 distributions $(16.7 \%$ vs $3.7 \%)$, which is prevalent in many African countries. This could be explained by the historical presence of Portugal in Africa and the more recent immigration of individuals from African countries. ${ }^{8}$

Until 2011, the combination of pegylated interferon and ribavirin for 24 or 48 weeks was the approved treatment for chronic hepatitis $\mathrm{C}$. With this regimen, patients infected with HCV genotype 1 had SVR rates of approximately $40 \%$ in North America and $50 \%$ in Western Europe. Higher SVR rates were achieved in patients infected with HCV genotypes 2 and 3 (up to about $80 \%$ and higher for genotype 2 than for genotype 3) and intermediate SVR rates were achieved in those with HCV genotype $4 .{ }^{4}$ In our population, direct-acting antivirals regimens resulted in remarkably high SVR rates compared to interferon-based regimens, which were consistent with the rates reported in clinical trials..$^{9-14}$ After implementation of the national program for the treatment of patients with chronic hepatitis $\mathrm{C}$, the cure rate was $96.5 \%{ }^{15}$ The selection of the direct-acting antivirals regimen was limited by the inclusion in the national program; this explains the high percentage of patients treated with regimens containing sofosbuvir and ledipasvir/ sofosbuvir. We observed a better SVR12 in genotype 1 compared with genotypes 2, 3 and 4. Although no comparative studies exist among regimens, all have very similar overall (SVR) rates of $>95 \%$ in a broad range of patients with the best response in genotype 1 compared with genotypes 2 and 4 in our population. ${ }^{2}$ Data suggest that advanced fibrosis (F3/F4), HIV coinfection and treatment failure with pegylated interferon plus ribavirin were not negatively related with SVR12 in our population. However, we observed a larger proportion of genotype 3 and 4, HCV RNA viral load $>800$ $000 \mathrm{IU} / \mathrm{mL}, \mathrm{HCV} / \mathrm{HIV}$ coinfection, advanced fibrosis (F3/ F4) and previous exposure to treatment in patients who relapsed when compared with patients who achieved SVR12. The cause or causes for this finding are not known and requires further analysis. In the relapsers, it was not possible to identify the reinfections. Today, the use of sofosbuvir plus ribavirin for genotype 3 treatment is considered suboptimal, so the introduction of new drugs in this setting justifies further research.

Table 1 - Rates of sustained virologic response by genotype

\begin{tabular}{|c|c|c|c|c|c|c|}
\hline & \multicolumn{6}{|c|}{ Genotype } \\
\hline & Overall & $1 a$ & $1 b$ & 2 & 3 & 4 \\
\hline All regimens & $\begin{array}{c}97.2 \% \\
797 / 820\end{array}$ & $\begin{array}{c}98.0 \% \\
344 / 351\end{array}$ & $\begin{array}{c}99.5 \% \\
187 / 188\end{array}$ & $\begin{array}{c}90.9 \% \\
10 / 11\end{array}$ & $\begin{array}{c}95.1 \\
116 / 122\end{array}$ & $\begin{array}{c}94.2 \\
129 / 137\end{array}$ \\
\hline LDV/ SOF \pm RBV & $\begin{array}{c}97.4 \% \\
642 / 659\end{array}$ & $\begin{array}{c}97.9 \% \\
333 / 340\end{array}$ & $\begin{array}{c}99.4 \% \\
169 / 170\end{array}$ & & $\begin{array}{c}87.5 \% \\
7 / 8\end{array}$ & $\begin{array}{c}93.9 \\
123 / 131\end{array}$ \\
\hline SOF + RBV & $\begin{array}{c}96.4 \% \\
106 / 110\end{array}$ & & & $\begin{array}{l}90 \% \\
9 / 10\end{array}$ & $\begin{array}{c}97 \% \\
96 / 99\end{array}$ & \\
\hline OBV/PTV/r \pm DSV \pm RBV & $\begin{array}{l}100 \% \\
28 / 28\end{array}$ & $\begin{array}{c}100 \% \\
7 / 7\end{array}$ & $\begin{array}{l}100 \% \\
16 / 16\end{array}$ & & & $\begin{array}{l}100.0 \\
5 / 5\end{array}$ \\
\hline SOF + DCV \pm RBV & $\begin{array}{c}92.9 \% \\
13 / 14\end{array}$ & & & $\begin{array}{c}100 \% \\
1 / 1\end{array}$ & $\begin{array}{c}92.3 \% \\
12 / 13\end{array}$ & \\
\hline
\end{tabular}

LDV/ SOF \pm RBV: ledipasvir/ sofosbuvir \pm ribavirin; SOF + RBV: sofosbuvir + ribavirin; OBV/PTV/r \pm DSV \pm RBV: ombitasvir/ paritaprevir/ ritonavir \pm dasabuvir \pm ribavirin; SOF + DCV \pm RBV: sofosbuvir + daclatasvir \pm ribavirin 
Table 2 - Baseline characteristics of responders and relapsers $(n=820)$

\begin{tabular}{|c|c|c|}
\hline & $\begin{array}{c}\text { SVR } \\
n=797\end{array}$ & $\begin{array}{c}\text { DAA relapsers } \\
n=23\end{array}$ \\
\hline \multicolumn{3}{|l|}{ Gender, \% (n) } \\
\hline Men & $67.4(537)$ & $69.6(16)$ \\
\hline Age, years old: mean (range) & $52.9(22-90)$ & $53(40-79)$ \\
\hline$>80$ years old, $\%(n)$ & $1.8(14)$ & $0(0)$ \\
\hline \multicolumn{3}{|l|}{ Genotype, \% (n) } \\
\hline $1 \mathrm{a}$ & $43.2(344)$ & $30.4(7)$ \\
\hline $1 \mathrm{~b}$ & $23.5(187)$ & $4.3(1)$ \\
\hline 1. unknown subtype & $1.0(8)$ & $0(0)$ \\
\hline 2 & $1.3(10)$ & $4.3(1)$ \\
\hline 3 & $14.6(116)$ & $26.1(6)$ \\
\hline 4 & $16.2(129)$ & $34.8(8)$ \\
\hline 5 & $0.3(2)$ & $0(0)$ \\
\hline 6 & $0.1(1)$ & $0(0)$ \\
\hline HCV RNA viral load, log UI/mL; mean (range) & $6.0(2.50-7.87)$ & $6.2(4.08-7.35)$ \\
\hline$>800000 \mathrm{lU} / \mathrm{mL}$ & $64.1(511)$ & $82.6(19)$ \\
\hline \multicolumn{3}{|l|}{ Coinfection, \% (n) } \\
\hline HCVI HIV & $31.9(254)$ & $34,8(8)$ \\
\hline \multicolumn{3}{|l|}{ Fibrosis stage, \% (n) } \\
\hline F0/ F1/ F2 & $47.3(377)$ & $30.4(7)$ \\
\hline F3/ F4 & $52.7(420)$ & $69.6(16)$ \\
\hline \multicolumn{3}{|l|}{ Child Pugh Score, \% (n) } \\
\hline A & $60.0(478)$ & $95.7(22)$ \\
\hline B & $2.9(23)$ & $4.3(1)$ \\
\hline Unknown & $37.1(290)$ & $0(0)$ \\
\hline \multicolumn{3}{|l|}{ Previous exposure to treatment, \% (n) } \\
\hline Naïve & $60.7(484)$ & $39.1(9)$ \\
\hline Null responder & $15.6(124)$ & $13.0(3)$ \\
\hline Relapser & $9.9(79)$ & $13.0(3)$ \\
\hline Partial responder & $4.4(35)$ & $13.0(3)$ \\
\hline Discontinuation due to $\mathrm{AE}$ & $7.8(62)$ & $13.0(3)$ \\
\hline Unknown response & $1.6(13)$ & $8.7(2)$ \\
\hline
\end{tabular}

All direct-acting antiviral combinations were well-tolerated by patients attesting to the much improved tolerability and convenience of these regimens expressed in clinical trials. $^{9-14}$

This study's strength is its ability to demonstrate the value of direct-acting antivirals based regimens in clinical practice.

\section{CONCLUSION}

These data provide an important extension to the available information on HCV treatment as it is the first real-world application of oral direct-acting antivirals in our population.

In conclusion, our data show that direct-acting antiviral based regimens are safe and have a high success rate in the treatment of patients with HCV infection in a real-life setting. Although direct-acting antivirals are promising in supporting sustained virologic response, interdisciplinary follow-up of these patients may improve both effectiveness and safety.

\section{PROTECTION OF HUMANS AND ANIMALS}

The authors declare that the procedures were followed according to the regulations established by the Clinical Research and Ethics Committee and to the Helsinki Declaration of the World Medical Association.

\section{DATA CONFIDENTIALITY}

The authors declare having followed the protocols in use at their working center regarding patients' data publication. Patient consent obtained. 


\section{CONFLICTS OF INTEREST}

The authors have no competing interests.

REFERENCES

1. Bourlière M, Gordon SC, Flamm SL, Cooper C L, Ramji A, Tong M,et al. Sofosbuvir, velpatasvir, and aoxilaprevir for previously treated HCV infection. N Engl J Med. 2017;376:2134-46.

2. Ioannou GN, Beste LA, Chang MF, Green M F, Lowy E, Tsui JI, et al. Effectiveness of sofosbuvir, ledipasvir/ sofosbuvir, or paritaprevir/ ritonavir/ ombitasvir and dasabuvir regimens for treatment of patients with hepatitis C in the Veterans Affairs National Health Care System. Gastroenterology. 2016;151:457-71.

3. Pockros, PJ. Direct-acting antivirals for the treatment of hepatitis $C$ virus infection [Internet]. UptoDate. 2017. [accessed 2017 Jul 11]. Available from: https://www.uptodate.com/contents/direct-acting-antivirals-forthe-treatment-of-hepatitis-c-virus-infection.

4. European Association for the Study of the Liver. EASL Recommendations on Treatment of Hepatitis C 2015. J Hepatol [Internet]. 2015. [accessed $2017 \mathrm{Jul}$ 05]. Available from: http://dx.doi.org/10.1016/j. jhep.2015.03.025.

5. Velosa J, Serejo F, Bana T, Redondo I, Simão A, Vale AM, et al. Chronic hepatitis $C$ treated with peginterferon alfa plus ribavirin in clinical practice. Hepatogastroenterology. 2011;58:1260-6.

6. Areias J, Gomes H, Mocho ML, Matos L, Valente C, Vale A. Epidemiological characterization of chronic hepatitis $C$ in Portugal. XXXI Congresso Anual da Fundação e Associação Espanhola para o Estudo do Fígado; 2006.

7. Petruzziello A, Marigliano S, Loquercio G, Cacciapuoti C. Hepatitis $\mathrm{C}$ virus (HCV) genotypes distribution: an epidemiological up-date in Europe. Infect Agent Cancer. 2016;11:1-9.

8. Illes J, Raghwani J, Harrison GL, Pepin J, Djoko CF, Tamoufe U, et al.

\section{FUNDING SOURCES}

This research received no specific grant from any funding agency in the public, commercial, or not-for-profit sectors.

Phylogeography and epidemic history of hepatitis $C$ virus genotype 4 in Africa. Virology. 2014;464:233-43.

9. Ferenci P, Bernstein D, Lalezari J, Cohen D, Luo Yan, Cooper C, et al ABT-450/r-Ombitasvir and dasabuvir with or without ribavirin for HCV. N Engl J Med. 2014;370:1983-92.

10. Jacobson IM, Gordon SC, Kowdley KV, Yoshida EM, Rodriguez-Torres M, Sulkowski MS, et al. Sofosbuvir for hepatitis C genotype 2 or 3 in patients without treatment options. N Engl J Med. 2013;368:1867-77.

11. Kowdley KV, Gordon SC, Reddy KR, Rossaro L, Bernstein DE, Lawitz E, et al. Ledipasvir and sofosbuvir for 8 or 12 weeks for chronic HCV without cirrhosis. N Engl J Med. 2014;370:1879-88.

12. Lawitz E, Poordad F, Gutierrez JA, Kakuda TN, Picchio G, Vandevoorde $A$, et al. Simeprevir, daclatasvir and sofosbuvir for hepatitis $C$ virusinfected patients with decompensated liver disease. J Viral Hepat. 2017;24:287-94.

13. Lawitz E, Mangia A, Wyles D, Rodriguez-Torres M, Hassanein T, Gordon SC, et al. Sofosbuvir for previously untreated chronic hepatitis C infection. N Engl J Med. 2016;368:1878-87.

14. Poordad F, Hezode C, Trinh R, Kowdley V, Zeuzem S, Agarwal K, et al. ABT-450/r-ombitasvir and dasabuvir with ribavirin for hepatitis $C$ with cirrhosis. N Engl J Med. 2014;370:1973-82.

15. Oito medicamentos disponíveis para tratar a hepatite C. [accessed on $2017 \mathrm{Jul}$ 14]. Available from: http://www.infarmed.pt/ documents/15786/1879176/Comunicado+de+Imprensa+-+Oito+Med icamentos+dispon\%C3\%ADveis+para+tratar+hepatite+C/be3e3873eebc-46cf-b147-8be6c2c81318. 